\title{
3 Research Square \\ Comparison of Ray Tracing and Monte Carlo Calculation Algorithms for Spine Lesions Treated with CyberKnife
}

Jun Li

Peking University Third Hospital

Xile Zhang

Peking University Third Hospital

Yuxi Pan

Peking University Third Hospital Ophthalmology Department

Hongqing Zhuang

Peking University Third Hospital

Ruijie Yang ( $\nabla$ ruijyang@yahoo.com )

Peking University Third Hospital

\section{Research Article}

Keywords: Cyberknife, Ray Tracing, Monte Carlo, stereotactic body radiation therapy

Posted Date: March 16th, 2021

DOl: https://doi.org/10.21203/rs.3.rs-280719/v1

License: (c) (1) This work is licensed under a Creative Commons Attribution 4.0 International License. Read Full License 


\section{Abstract}

Purpose: This study attempts to evaluate Ray Tracing (RT) and Monte Carlo (MC) algorithm for CyberKnife treatments of spine lesions and determine whether $\mathrm{MC}$ algorithm is necessary for all spine treatment and analyze which sites of spine lesion for which RT algorithm is comparable to MC algorithm.

Methods: The CyberKnife is used for stereotactic body radiotherapy for lesions in the cervical spine (30), thoracic spine (50), lumbar spine (30) and sacral spine (15). Dose was calculated using RT and MC algorithms for patients planned with the same beam angles and monitor units. Dose-volume histograms of the target and selected critical structures are evaluated.

Results: The average target coverage of prescribed dose with MC algorithms was $94.80 \%, 88.47 \%$, $92.52 \%$ and $93.41 \%$ respectively in cervical, thoracic, lumbar and sacral spine. For thoracic spine, RT algorithm significantly overestimates the percentage volume of target covered by the prescribed dose, as well as overestimates doses to organs at risk in most cases, including lung, spinal cord and esophagus. For cervical, lumbar and sacral spine, the differences of the target coverage of prescription dose were generally less than $3 \%$ between the RT and $\mathrm{MC}$ algorithms. The differences of doses to organs at risk varied with lesion sites and surrounding organs.

Conclusions: In the thoracic spine lesions with beams through air cavities, RT algorithm should be limited and verified with $\mathrm{MC}$ algorithm, but the RT algorithm is adequate for treatment of cervical, lumbar and sacral spine lesions without or small amount of beams passing through the lungs.

\section{Introduction}

Stereotactic body radiation therapy (SBRT) technology has the potential to increase the dose of the tumor and reduce the dose to normal tissue, so it can obtain higher tumor control probability and lower normal tissue complication probability ${ }^{[1]}$. As the typical equipment for SBRT technology, CyberKnife (CK) has been increasingly used for spinal lesion treatment in modern radiotherapy. However, non-isocentric noncoplanar beams of SBRT based on CK are more complicated than conventional radiotherapy. Thus, the accuracy of dose calculation is crucial for effective treatment.

Two types of dose calculation algorithms: ray tracing (RT) and Monte Carlo (MC) are used for CK. There are many studies that have reported that the dose calculated by the RT and MC algorithms were significantly different in heterogeneous tissues. The degree of difference is influenced by many factors, including tumor size, location, peripheral tissue characteristics and collimator aperture ${ }^{[2-5]}$. Compared to the RT algorithm, the Monte Carlo algorithm is able to take into consideration the tissue heterogeneities, meanwhile density scaling functions and effective depth correction factors are not required ${ }^{[6-7]}$. Therefore, the $\mathrm{MC}$ algorithm for $\mathrm{CK}$ could provide more accurate dose distribution calculations in regions of lateral electron disequilibrium. However, dose optimization of the $\mathrm{MC}$ algorithm is computationally cumbersome, requiring more time to carry out, particularly with lower uncertainty levels. Compared with 
the RT algorithm, the MC algorithm needs more computing power and personnel time remarkably ${ }^{[8-9]}$. Given the current state of technology and computing power, there exists a limitation to the clinical implementation of quality MC-calculated treatment plans. Moreover, some studies have shown that the dosimetric difference between RT and MC may not be appreciable significantly, such as treatment sites with quasi-homogeneous tissues ${ }^{[10]}$.

In addition, due to the specific geometry of the CK layout, the space below the treatment couch plane cannot be accessed by CK. The posterior radiation beams for patients are prohibited in supine position. Thus beams aimed at posterior spinal lesions had to traverse a substantial length of normal tissues on their way to the target. As we know, the spine is composed of cervical vertebrae, thoracic vertebrae, lumbar vertebrae and sacrum bone. There are various adjacent tissues closed to different types of vertebrae. These tissues include homogeneous tissues, such as the spinal cord, the kidneys and heterogeneous tissues such as the lungs, the esophagus, the intestinal tract and so on. Therefore, the relationship between the spine and its neighboring tissues is quite complex. For spine lesions, it is unknown whether it is necessary for all lesions of the spine using the $\mathrm{MC}$ algorithm to improve the dose calculation accuracy or whether the treatment plan with the RT algorithm could be acceptable in clinical treatment. Due to the lack of data on the choice of the algorithm in previous studies, this question needs further exploration. In our study, dose distributions calculated by MC and RT are compared for patients with cervical, thoracic, lumbar, and sacral spine lesions, and to determine whether CK based SBRT using $\mathrm{RT}$ algorithm is comparable dosimetrically to that of $\mathrm{MC}$ for spinal lesions.

\section{Methods}

\subsection{Treatment planning and dose prescription}

This is a retrospective study on spinal tumor patients treated with SBRT by CyberKnife VSI (Accuray Inc., Sunnyvale, CA) from 2018 to 2020 . The study was approved by the institutional review board of our hospital. One hundred twenty-five spinal lesions were treated, 30 for the cervical spine, 50 for the thoracic spine, 30 for the lumbar spine and 15 for the sacral spine.

Patients were simulated in the supine position. CT scan was acquired with a slice thickness of $1.5 \mathrm{~mm}$ and used for structures delineation and dose calculation. The first and second cervical spinal tumors of treatment plans were designed using the 6D-Skull tracking method, other sites using the spine tracking method. The dose was calculated using the RT algorithm in the CyberKnife TPS MultiPlan v.4.6 (Accuray Inc.). Treatment plans were generated using 1-4 IRIS aperture collimators and an average 148 (range 104-227) non-coplanar non-isocentric beams. The smallest collimator was $10 \mathrm{~mm}$ in diameter, and the largest collimator was $60 \mathrm{~mm}$ in diameter. The size of dose calculation grid $x$ and $y$ is less than $1 \mathrm{~mm}, z$ is $1.5 \mathrm{~mm}$. Characteristics of the patient and associated plan parameters are shown in Table 1. The PTV volume ranged from $51.7 \mathrm{cc}$ to $319.8 \mathrm{cc}$. Patients were treated in 3 fractions with a dose of 24-30Gy. The PTV dose was prescribed at $68 \%-84 \%$ isodose level. The dose coverage of PTV ranged from $93.9-96.8 \%$. 
Table 1

Patient and tumor characteristics

\begin{tabular}{|c|c|c|c|c|c|c|c|}
\hline Site & $\begin{array}{l}\text { Number } \\
\text { of } \\
\text { patients }\end{array}$ & $\begin{array}{l}\text { Tumor } \\
\text { location }\end{array}$ & $\begin{array}{l}\text { Prescription } \\
\text { dose (Gy) }\end{array}$ & $\begin{array}{l}\text { Number } \\
\text { of } \\
\text { fractions }\end{array}$ & $\begin{array}{l}\text { Prescription } \\
\text { Isodose }\end{array}$ & $\begin{array}{l}\text { Collimator } \\
\text { Sizes } \\
(\mathrm{mm})\end{array}$ & $\begin{array}{l}\text { PTV } \\
\text { Volume } \\
\text { (cc) }\end{array}$ \\
\hline \multirow{3}{*}{$\begin{array}{l}\text { Cervical } \\
\text { spine }\end{array}$} & 9 & C1-2 & $27-30$ & \multirow[t]{3}{*}{3} & \multirow[t]{3}{*}{ 70\%-77\% } & \multirow[t]{3}{*}{$10-50$} & \multirow{3}{*}{$\begin{array}{l}87.2- \\
204.6\end{array}$} \\
\hline & 14 & C3-5 & $24-30$ & & & & \\
\hline & 7 & C6-7 & $27-30$ & & & & \\
\hline \multirow{4}{*}{$\begin{array}{l}\text { Thoracic } \\
\text { spine }\end{array}$} & 14 & T1-3 & $27-30$ & \multirow[t]{4}{*}{3} & \multirow[t]{4}{*}{$68 \%-80 \%$} & \multirow[t]{4}{*}{$12.5-50$} & \multirow{4}{*}{$\begin{array}{l}51.7- \\
303.5\end{array}$} \\
\hline & 11 & $\mathrm{~T} 4-6$ & $24-30$ & & & & \\
\hline & 10 & T7-9 & $27-30$ & & & & \\
\hline & 15 & T10-12 & $24-30$ & & & & \\
\hline \multirow{2}{*}{$\begin{array}{l}\text { Lumbar } \\
\text { spine }\end{array}$} & 13 & L1-2 & $24-30$ & \multirow[t]{2}{*}{3} & \multirow[t]{2}{*}{$69 \%-81 \%$} & \multirow[t]{2}{*}{$10-60$} & \multirow{2}{*}{$\begin{array}{l}108.3- \\
319.8\end{array}$} \\
\hline & 17 & L3-5 & $24-30$ & & & & \\
\hline $\begin{array}{l}\text { Sacral } \\
\text { spine }\end{array}$ & 15 & S1 & $27-30$ & 3 & $71 \%-84 \%$ & $12.5-60$ & $\begin{array}{l}67.4- \\
228.1\end{array}$ \\
\hline
\end{tabular}

\subsection{Plans recalculated using MC Algorithm}

Based on the plans computed using the RT algorithm introduced above, plans were recalculated using the $\mathrm{MC}$ algorithm without re-optimization. For the MC calculation, the collimator size, the number of beams, and the monitor units were kept unchanged from the original RT plans. The prescription for each plan was not renormalized. MC plans were calculated using high-resolution mode with a clinically meaningful uncertainty level of $1.5 \%$.

\subsection{Dosimetric comparison between Ray Tracing and Monte Carlo algorithms}

Dose calculated using the $\mathrm{MC}$ and $\mathrm{RT}$ algorithms, was compared by analyzing the dose-volume histograms (DVHs) for the PTV and OARs. PTV was assessed by $\mathrm{V}_{100}$. For the OARs, $\mathrm{V}_{5}$ and mean dose were used for the lung. The maximum dose, $D_{0.1 c c}, D_{1 c c}$ and $D_{5 c c}$ were used for the esophagus, spinal cord and bowels. Mean dose and $\mathrm{V}_{16}$ were used for the kidneys. Comparison between the dosimetric parameters generated by the RT and MC algorithms were analyzed with a t-test. P-value below 0.01 indicates statistically significant differences between mean values of the data sets.

\section{Results}




\subsection{Dosimetric comparisons between RT and MC for cervical spine}

Figure 1 demonstrated the dose distribution and DVHs for cervical spine lesions between the RT and MC algorithms. There was no significant difference for target and OARs. Compared with the region of high dose, the change of the low dose region is relatively obvious. In order to quantify specifically the effect on the dose differences using the RT and MC algorithms, the dosimetric parameters were given in Table 2 . For C1-2, compared to MC plans, the $\mathrm{V}_{100}$ of PTV is on average $0.88 \%$ lower in RT plans, and the average $\mathrm{RT} / \mathrm{MC}$ ratio of PTV $\mathrm{V}_{100}$ was 0.990 , ranged from 0.984 to 1.012 . For C3-7, compared to MC plans, the $\mathrm{V}_{100}$ of PTV was on average $1.41 \%$ higher in RT plans. The Average RT/MC ratio of PTV $\mathrm{V}_{100}$ was 1.015 , ranged from 0.989 to 1.021 . For OARs, there was no significant discrepancy between RT and MC algorithms. RT/MC ratio ranged from 0.978 to 1.023 for dosimetric parameters of the spinal cord and esophagus. 
Table 2

Dose parameters of cervical spine lesions

\begin{tabular}{|c|c|c|c|c|}
\hline Site & Dosimetric parameter & $\begin{array}{l}\text { Ray Tracing } \\
\text { (mean } \pm \text { SD) }\end{array}$ & $\begin{array}{l}\text { Monte Carlo } \\
\text { (mean } \pm \text { SD) }\end{array}$ & P-Value \\
\hline \multirow[t]{12}{*}{ C1-2 } & PTV & & & \\
\hline & $\mathrm{V}_{100 \%}$ & $95.40 \% \pm 0.43 \%$ & $96.28 \% \pm 1.41 \%$ & $<0.01$ \\
\hline & Spinal Cord & & & \\
\hline & $\mathrm{D}_{\max }(\mathrm{Gy})$ & $24.15 \pm 3.94$ & $24.48 \pm 3.83$ & 0.12 \\
\hline & $\mathrm{D}_{0.1 \mathrm{cc}}(\mathrm{Gy})$ & $20.66 \pm 3.98$ & $21.09 \pm 3.84$ & 0.08 \\
\hline & $\mathrm{D}_{1 \mathrm{cc}}(\mathrm{Gy})$ & $15.85 \pm 4.79$ & $16.13 \pm 4.74$ & 0.15 \\
\hline & $\mathrm{D}_{5 \mathrm{cc}}(\mathrm{Gy})$ & $10.23 \pm 6.77$ & $10.40 \pm 6.33$ & 0.46 \\
\hline & Oral mucosa & & & \\
\hline & $\mathrm{D}_{\max }(\mathrm{Gy})$ & $24.86 \pm 67.3$ & $25.00 \pm 6.92$ & 0.17 \\
\hline & $\mathrm{D}_{0.1 \mathrm{cc}}(\mathrm{Gy})$ & $23.20 \pm 6.60$ & $23.31 \pm 6.72$ & 0.51 \\
\hline & $\mathrm{D}_{1 \mathrm{cc}}(\mathrm{Gy})$ & $20.14 \pm 6.25$ & $20.27 \pm 6.47$ & 0.33 \\
\hline & $D_{5 c c}(G y)$ & $15.85 \pm 5.38$ & $15.93 \pm 5.69$ & 0.42 \\
\hline \multirow[t]{11}{*}{ C3-7 } & PTV & & & \\
\hline & $V_{100}$ & $95.33 \% \pm 0.50 \%$ & $93.92 \% \pm 1.27 \%$ & $<0.01$ \\
\hline & Spinal Cord & & & \\
\hline & $\mathrm{D}_{\max }(\mathrm{Gy})$ & $25.15 \pm 2.71$ & $24.74 \pm 2.58$ & 0.02 \\
\hline & $\mathrm{D}_{0.1 \mathrm{cc}}(\mathrm{Gy})$ & $22.42 \pm 3.24$ & $22.15 \pm 3.06$ & 0.08 \\
\hline & $\mathrm{D}_{1 \mathrm{cc}}(\mathrm{Gy})$ & $17.53 \pm 4.82$ & $16.97 \pm 4.52$ & 0.05 \\
\hline & $\mathrm{D}_{5 \mathrm{cc}}(\mathrm{Gy})$ & $8.65 \pm 6.52$ & $8.24 \pm 6.53$ & 0.42 \\
\hline & Esophagus & & & \\
\hline & Dmax & $27.04 \pm 3.48$ & $26.69 \pm 3.12$ & 0.07 \\
\hline & $\mathrm{D}_{0.1 \mathrm{cc}}(\mathrm{Gy})$ & $24.81 \pm 4.74$ & $24.34 \pm 4.26$ & 0.21 \\
\hline & $\mathrm{D}_{1 \mathrm{cc}}(\mathrm{Gy})$ & $20.72 \pm 4.96$ & $20.34 \pm 4.58$ & 0.13 \\
\hline
\end{tabular}




\section{Site Dosimetric parameter Ray Tracing Monte Carlo P-Value $($ mean \pm SD $) \quad($ mean \pm SD) \\ $\mathrm{D}_{5 \mathrm{cc}}$ (Gy) $\quad 13.56 \pm 5.18 \quad 13.24 \pm 4.70 \quad 0.07$ \\ 3.2 Dosimetric comparisons between RT and MC algorithms for thoracic spine}

Table 3 shows the results using RT and MC algorithms for target and OARs in the Thoracic spine. The dose discrepancy in T1-3 and T10-12 was smaller than in T4-9 between the RT and MC algorithms. For T1-3 and T10-12, compared to MC plans, $\mathrm{V}_{100}$ of PTV was on average $3.07 \%$ and $3.58 \%$ lower in RT plans. In T1-3, the average RT/MC ratio of PTV $\mathrm{V}_{100}$ was 1.034, range from 1.017 to 1.042. In T10-12, the average RT/MC ratio of PTV $V_{100}$ was 1.039, range from 1.026 to 1.048. For these two sites, there was no significant dosimetric discrepancy in the esophagus and spinal cord, and RT/MC ratio ranged from 0.976 to 1.030. The average deviation in $\mathrm{V}_{5}$ of lung between $\mathrm{MC}$ and $\mathrm{RT}$ algorithms were generally less than $3 \%$, and the average $\mathrm{RT} / \mathrm{MC}$ ratio of $\mathrm{D}_{\text {mean }}$ was 1.038 , ranged from 0.984 to 1.048 . 
Table 3

Dose parameters of thoracic lesions

\begin{tabular}{|c|c|c|c|c|}
\hline Site & Dosimetric parameter & $\begin{array}{l}\text { Ray Tracing } \\
\text { (mean } \pm S D \text { ) }\end{array}$ & $\begin{array}{l}\text { Monte Carlo } \\
\text { (mean } \pm \text { SD) }\end{array}$ & P-Value \\
\hline \multirow[t]{18}{*}{ T1-3 } & PTV & & & \\
\hline & $\mathrm{V}_{100 \%}$ & $94.93 \% \pm 0.39 \%$ & $91.86 \% \pm 3.46 \%$ & $<0.01$ \\
\hline & Spinal Cord & & & \\
\hline & $\mathrm{D}_{\max }(\mathrm{Gy})$ & $22.01 \pm 1.88$ & $21.59 \pm 2.01$ & 0.02 \\
\hline & $\mathrm{D}_{0.1 \mathrm{cc}}(\mathrm{Gy})$ & $19.44 \pm 3.22$ & $18.90 \pm 2.42$ & 0.03 \\
\hline & $\mathrm{D}_{1 \mathrm{cc}}(\mathrm{Gy})$ & $15.85 \pm 1.79$ & $15.46 \pm 2.00$ & 0.33 \\
\hline & $D_{5 c c}(G y)$ & $10.23 \pm 3.49$ & $10.11 \pm 3.15$ & 0.46 \\
\hline & Esophagus & & & \\
\hline & $\mathrm{D}_{\max }(\mathrm{Gy})$ & $25.10 \pm 2.23$ & $24.36 \pm 2.03$ & 0.02 \\
\hline & $\mathrm{D}_{0.1 \mathrm{cc}}(\mathrm{Gy})$ & $22.07 \pm 1.47$ & $21.25 \pm 2.06$ & 0.02 \\
\hline & $\mathrm{D}_{1 \mathrm{cc}}(\mathrm{Gy})$ & $19.20 \pm 1.74$ & $18.51 \pm 1.62$ & 0.02 \\
\hline & $\mathrm{D}_{5 \mathrm{cc}}(\mathrm{Gy})$ & $13.69 \pm 2.51$ & $13.02 \pm 2.14$ & 0.42 \\
\hline & Left Lung & & & \\
\hline & $\mathrm{V}_{5}$ & $20.2 \% \pm 4.6 \%$ & $19.1 \% \pm 8.4 \%$ & 0.02 \\
\hline & $\mathrm{D}_{\text {mean }}(\mathrm{Gy})$ & $3.21 \pm 0.48$ & $3.15 .3 \pm 0.71$ & 0.04 \\
\hline & Right Lung & & & \\
\hline & $\mathrm{V}_{5}$ & $26.8 \% \pm 6.7 \%$ & $24.3 \% \pm 9.3 \%$ & 0.02 \\
\hline & $\mathrm{D}_{\text {mean }}(\mathrm{Gy})$ & $4.75 \pm 1.06$ & $4.67 \pm 1.23$ & 0.02 \\
\hline \multirow[t]{5}{*}{ T4-9 } & PTV & & & \\
\hline & $V_{100 \%}$ & $95.22 \% \pm 0.51 \%$ & $82.67 \% \pm 13.68 \%$ & $<0.01$ \\
\hline & Spinal Cord & & & \\
\hline & $\mathrm{D}_{\max }$ & $22.80 \pm 3.93$ & $21.76 \pm 4.24$ & $<0.01$ \\
\hline & $\mathrm{D}_{0.1 \mathrm{cc}}(\mathrm{Gy})$ & $19.28 \pm 3.81$ & $18.32 \pm 3.57$ & $<0.01$ \\
\hline
\end{tabular}




\begin{tabular}{|c|c|c|c|c|}
\hline Site & Dosimetric parameter & $\begin{array}{l}\text { Ray Tracing } \\
\text { (mean } \pm S D \text { ) }\end{array}$ & $\begin{array}{l}\text { Monte Carlo } \\
\text { (mean } \pm S D)\end{array}$ & P-Value \\
\hline & $\mathrm{D}_{1 \mathrm{cc}}(\mathrm{Gy})$ & $16.82 \pm 4.45$ & $16.47 \pm 4.02$ & 0.05 \\
\hline & $D_{5 c c}(G y)$ & $7.49 \pm 5.06$ & $7.22 \pm 5.61$ & 0.42 \\
\hline & \multicolumn{4}{|l|}{ Esophagus } \\
\hline & $D_{\max }(G y)$ & $23.57 \pm 3.52$ & $22.48 \pm 2.84$ & $<0.01$ \\
\hline & $\mathrm{D}_{0.1 \mathrm{cc}}(\mathrm{Gy})$ & $21.22 \pm 3.27$ & $20.16 \pm 3.53$ & $<0.01$ \\
\hline & $\mathrm{D}_{1 \mathrm{cc}}(\mathrm{Gy})$ & $18.46 \pm 3.83$ & $17.94 \pm 3.53$ & 0.03 \\
\hline & $D_{5 c c}(G y)$ & $13.86 \pm 4.35$ & $13.34 \pm 4.67$ & 0.02 \\
\hline & \multicolumn{4}{|l|}{ Left Lung } \\
\hline & $\mathrm{V}_{5}$ & $28.40 \% \pm 18.4 \%$ & $25.97 \pm 13.80 \%$ & $<0.01$ \\
\hline & $\mathrm{D}_{\text {mean }}(\mathrm{Gy})$ & $5.77 \pm 1.83$ & $5.29 \pm 1.55$ & $<0.01$ \\
\hline & \multicolumn{4}{|l|}{ Right Lung } \\
\hline & $v_{5}$ & $34.2 \% \pm 18.9 \%$ & $31.8 \% \pm 15.2 \%$ & $<0.01$ \\
\hline & $\mathrm{D}_{\text {mean }}(\mathrm{Gy})$ & $6.53 \pm 2.25$ & $6.01 \pm 1.72$ & $<0.01$ \\
\hline \multirow[t]{11}{*}{ T10-12 } & \multicolumn{4}{|l|}{ PTV } \\
\hline & $V_{100 \%}$ & $95.14 \% \pm 0.27 \%$ & $91.56 \% \pm 2.18 \%$ & $<0.01$ \\
\hline & \multicolumn{4}{|l|}{ Spinal Cord } \\
\hline & $\mathrm{D}_{\max }$ & $22.61 \pm 2.80$ & $22.09 \pm 2.89$ & 0.02 \\
\hline & $\mathrm{D}_{0.1 \mathrm{cc}}(\mathrm{Gy})$ & $20.71 \pm 2.39$ & $20.14 \pm 2.52$ & 0.05 \\
\hline & $\mathrm{D}_{1 \mathrm{cc}}(\mathrm{Gy})$ & $18.01 \pm 241$ & $17.57 \pm 2.45$ & 0.03 \\
\hline & $D_{5 c c}(G y)$ & $94.2 \pm 6.74$ & $9.13 \pm 7.20$ & 0.07 \\
\hline & \multicolumn{4}{|l|}{ Esophagus } \\
\hline & $\mathrm{D}_{\max }(\mathrm{Gy})$ & $20.71 \pm 3.78$ & $20.28 \pm 4.14$ & 0.07 \\
\hline & $\mathrm{D}_{0.1 \mathrm{cc}}(\mathrm{Gy})$ & $18.83 \pm 4.15$ & $18.60 \pm 4.14$ & 0.21 \\
\hline & $\mathrm{D}_{1 \mathrm{cc}}(\mathrm{Gy})$ & $16.35 \pm 4.74$ & $15.93 \pm 5.01$ & 0.01 \\
\hline
\end{tabular}




\begin{tabular}{|c|c|c|c|c|}
\hline Site & Dosimetric parameter & $\begin{array}{l}\text { Ray Tracing } \\
\text { (mean } \pm S D \text { ) }\end{array}$ & $\begin{array}{l}\text { Monte Carlo } \\
\text { (mean } \pm S D \text { ) }\end{array}$ & P-Value \\
\hline & $D_{5 c c}(G y)$ & $12.75 \pm 5.76$ & $12.31 \pm 5.95$ & 0.01 \\
\hline & \multicolumn{4}{|l|}{ Left Lung } \\
\hline & $v_{5}$ & $21.11 \% \pm 14.8 \%$ & $19.81 \% \pm 13.90 \%$ & 0.02 \\
\hline & $\mathrm{D}_{\text {mean }}(\mathrm{Gy})$ & $4.36 \pm 2.42$ & $4.21 \pm 1.61$ & 0.03 \\
\hline & \multicolumn{4}{|l|}{ Right Lung } \\
\hline & $\mathrm{V}_{5}$ & $15.22 \% \pm 8.6 \%$ & $14.72 \% \pm 10.7 \%$ & 0.02 \\
\hline & $\mathrm{D}_{\text {mean }}(\mathrm{Gy})$ & $3.66 \pm 1.56$ & $3.53 \pm 1.34$ & 0.03 \\
\hline
\end{tabular}

For T4-9, the average $\mathrm{V}_{100}$ of PTV was $12.55 \%$ lower in MC plans than RT plans, the average RT/MC ratio of PTV $V_{100}$ was 1.15, range from 1.066 to 1.381 . Maximum dose and $D_{0.1 c c}$ for spinal cord and esophagus were statistically different $(\mathrm{P}<0.01)$ between $\mathrm{RT}$ and $\mathrm{MC}$ algorithms. RT/MC ratio of the spinal cord in the maximum dose and $D_{0.1 \mathrm{cc}}$ ranged from 0.942 to 1.092 , and 0.966 to 1.089 , respectively. $\mathrm{RT} / \mathrm{MC}$ ratio of the esophagus in the maximum dose and $\mathrm{D}_{0.1 \mathrm{cc}}$ ranged from 0.957 to 1.078 , and 0.982 to 1.058 , respectively. Meanwhile $D_{\text {mean }}$ and $V_{5}$ for lungs were statistically different $(P<0.01)$. The average deviations were generally less than $5 \%$ in $V_{5}$ and less than $10 \%$ in $D_{\text {mean }}$. Based on the results shown in Fig. 2, we found that the RT algorithm obviously overestimated the $V_{100}$ of PTV compared to the MC algorithm. Moreover, at the lung-bone interface, the isodose line tends to pull toward the spine, and the target closest to the lung will have the highest dose falloff. Therefore, the minimum dose of target decreased observably at the lung-bone interface. In addition, the RT algorithm slightly overestimated the dose to lung compared to the MC algorithm. However, for other OARs farther away from the target (low dose region of OARs), the differences between $\mathrm{MC}$ and $\mathrm{RT}$ algorithms were almost negligible.

\subsection{Dosimetric comparisons between RT and MC algorithms for lumbar spine}

Table 4 shows the comparison of dosimetric parameters between RT and MC algorithms for target and OARs in the lumbar spine. The average $\mathrm{V}_{100}$ of PTV was $2.44 \%$ greater in MC plans than RT plans, and the average RT/MC ratio was 1.026 , ranged from 1.008 to 1.032 . We found it was still inevitable that a small number of beams would penetrate the lung tissue in L1 or L2 plans. So target coverage of prescription dose would be lower than other lumbar spines. For OARs, the dose difference between the RT and $\mathrm{MC}$ algorithms was not remarkable, and $\mathrm{RT} / \mathrm{MC}$ ratio ranged from 0.982 to 1.028 . From DVHs shown in Fig. 3 , the coverage of PTV and dose of OARs was basically unchanged. 
Table 4

Dose parameters of lumbar lesions

\begin{tabular}{|c|c|c|c|c|}
\hline Site & Dosimetric parameter & $\begin{array}{l}\text { Ray Tracing } \\
\text { (mean } \pm S D \text { ) }\end{array}$ & $\begin{array}{l}\text { Monte Carlo } \\
\text { (mean } \pm \text { SD) }\end{array}$ & p-Value \\
\hline \multirow[t]{23}{*}{ L1-5 } & PTV & & & \\
\hline & $V_{100 \%}$ & $95.3 \% \pm 0.58 \%$ & $92.86 \% \pm 1.14 \%$ & $<0.01$ \\
\hline & Spinal Cord/ & & & \\
\hline & Cauda equina & & & \\
\hline & $\mathrm{D}_{\max }$ & $25.80 \pm 4.35$ & $25.54 \pm 4.46$ & 0.02 \\
\hline & $\mathrm{D}_{0.1 \mathrm{cc}}(\mathrm{Gy})$ & $23.83 \pm 4.60$ & $23.54 \pm 4.97$ & 0.08 \\
\hline & $\mathrm{D}_{1 \mathrm{cc}}(\mathrm{Gy})$ & $20.71 \pm 4.14$ & $20.49 \pm 4.50$ & 0.15 \\
\hline & $D_{5 c c}(G y)$ & $12.60 \pm 4.49$ & $12.46 \pm 4.95$ & 0.46 \\
\hline & Bowel & & & \\
\hline & Dmax & $23.28 \pm 3.14$ & $22.93 \pm 2.35$ & 0.17 \\
\hline & $\mathrm{D}_{0.1}(\mathrm{~Gy})$ & $22.01 \pm 3.86$ & $21.89 \pm 3.09$ & 0.51 \\
\hline & $\mathrm{D}_{1 \mathrm{cc}}(\mathrm{Gy})$ & $20.21 \pm 4.06$ & $20.55 \pm 6.48$ & 0.33 \\
\hline & $\mathrm{D}_{5 \mathrm{cc}}(\mathrm{Gy})$ & $16.69 \pm 4.04$ & $16.96 \pm 4.86$ & 0.04 \\
\hline & Stomach & & & \\
\hline & Dmax & $16.72 \pm 7.34$ & $16.62 \pm 7.18$ & 0.04 \\
\hline & $\mathrm{D}_{0.1}(\mathrm{~Gy})$ & $14.64 \pm 6.89$ & $14.51 \pm 6.52$ & 0.45 \\
\hline & $\mathrm{D}_{1 \mathrm{cc}}(\mathrm{Gy})$ & $12.40 \pm 7.03$ & $12.18 \pm 7.18$ & 0.06 \\
\hline & $\mathrm{D}_{5 \mathrm{cc}}(\mathrm{Gy})$ & $10.13 \pm 6.55$ & $9.78 \pm 6.73$ & 0.02 \\
\hline & Left Kidney & & & \\
\hline & $\mathrm{D}_{\text {mean }}(\mathrm{Gy})$ & $10.24 \pm 3.48$ & $10.59 \pm 3.12$ & 0.07 \\
\hline & $\mathrm{V}_{1600}(\mathrm{cc})$ & $81.30 \pm 4.40$ & $79.7 \pm 6.20$ & 0.21 \\
\hline & Right Kidney & & & \\
\hline & $\mathrm{D}_{\text {mean }}(\mathrm{Gy})$ & $12.28 \pm 4.74$ & $12.14 \pm 4.26$ & 0.11 \\
\hline
\end{tabular}




\begin{tabular}{|lllll|}
\hline Site & Dosimetric parameter & $\begin{array}{l}\text { Ray Tracing } \\
(\text { mean } \pm \text { SD) }\end{array}$ & $\begin{array}{l}\text { Monte Carlo } \\
(\text { mean } \pm \text { SD) }\end{array}$ & p-Value \\
\hline $\mathrm{V}_{1600}(\mathrm{cc})$ & $10.43 \pm 4.96$ & $10.29 \pm 4.58$ & 0.13 \\
\hline
\end{tabular}

\subsection{Dosimetric comparisons between RT and MC algorithms for sacral spine}

The comparison of the dosimetric parameter between RT and MC calculations for target and OARs of the sacral spine was shown in Table 5. The average PTV coverage of prescription dose calculated using RT algorithm was uniformly better than the average PTV coverage using MC by up to $1.36 \%$, and RT/MC ratio ranged from 1.003 to 1.019 . For OARs, the dose deviation between the RT and MC algorithms was not remarkable and RT/MC ratio ranged from 0.982 to 1.028. As shown in Fig. 4, the increased dose was displayed in RT plans compared to MC plans in DVHs. But the dose distribution of the MC algorithm was closer to the RT algorithm for OARs and PTV coverage of prescription dose.

Table 5

Dose parameters of sacral lesions

\begin{tabular}{|lllll|}
\hline Site & Dosimetric parameter & Ray Tracing (mean \pm SD) & Monte Carlo (mean \pm SD) & p-Value \\
\hline S1 & PTV & $95.23 \% \pm 0.67 \%$ & $93.87 \% \pm 1.02 \%$ & \\
\hline$V_{100 \%}$ & & & $<0.01$ \\
\hline Cauda equina & $23.51 \pm 3.44$ & $23.38 \pm 3.24$ & 0.02 \\
\hline$D_{\max }$ & $20.80 \pm 3.69$ & $20.90 \pm 3.54$ & 0.02 \\
\hline$D_{0.1 c c}$ & $15.85 \pm 4.03$ & $15.73 \pm 3.88$ & 0.15 \\
\hline$D_{1 c c}$ & $12.13 \pm 3.77$ & $12.22 \pm 3.34$ & 0.46 \\
\hline$D_{5 c c}$ & & & 0.17 \\
\hline$B$ Bwel & $24.91 \pm 5.64$ & $24.70 \pm 5.42$ & 0.32 \\
\hline$D_{\max }$ & $23.01 \pm 5.60$ & $23.15 \pm 5.47$ & 0.51 \\
\hline$D_{0.1}$ & $20.34 \pm 5.25$ & $20.25 \pm 5.18$ & 0.04 \\
\hline$D_{1 c c}$ & $15.85 \pm 5.46$ & $15.54 \pm 5.33$ & \\
\hline$D_{5 c c}$ & & & \\
\hline
\end{tabular}

\section{Discussions}


CK is a widely used modality to treat spinal tumors due to its highly conformal dose distributions, steep gradient, and near real-time image-guidance system ${ }^{[11-13]}$. The CK-based SBRT appears to be safe and effective at tumor control and symptom management in spinal patients ${ }^{[14-15]}$.

Meanwhile, CK spinal radiosurgery suffers from a lack of posterior beams due to mechanic design limitations, so that many beams pass through other tissues before reaching the spine lesions. Thus, the dose-relationship between spinal lesions of different sites and their adjacent organs is extremely complicated. Tissue heterogeneity correction will have a major effect on dose distribution. However, at present, dose calculation methods have not been strictly specified in clinical trials of spine SBRT. Although MC-based methods are increasingly recognized as the most appropriate. It has an uncertainty associated with the calculation results and needs to add significantly to the treatment planning time ${ }^{[16-}$ 17]. Therefore, not all sites will benefit from the MC algorithm.

How to balance the time efficiency and calculation accuracy, strategy of algorithm selection is the key. Our institutional datasets with spine SBRT were reviewed to determine the impact of RT versus MC algorithm on target coverage and dose exposure to the OARs. For the cervical spine, the coverage of the target using MC algorithm was slightly increased compared to the RT algorithm for some plans of $\mathrm{C} 1$ and/or C2. For the C3-C7, lumbar spine and sacral spine, the RT algorithm commonly decreased the coverage of targets in small amounts. No significant dose differences were found for the OARs between the two algorithms. The deviation in the dose of OARs and coverage of target resulted in a maximum of $3.2 \%$ when comparing the RT algorithm with the $\mathrm{MC}$ algorithm. These results were similar to the previous study that showed the calculation algorithms RT and MC were equivalent in relatively homogeneous regions with dose deviation within $4 \%{ }^{[10]}$. The discrepancy in these values would not have been a determining factor as to which algorithm to utilize in treatment. Thus, the use of the RT algorithm in cervical, lumbar and sacral spine lesions is to be regarded as sufficient and appropriate.

However, this situation was markedly changed in the heterogeneous tissue with $\mathrm{MC}$ calculation. For the thoracic spine, a significant difference in the dose distribution between the RT and MC algorithm is detected. Especially, in the middle thoracic spine (T6-T9), the MC algorithm resulted in an average loss in the coverage of PTV about $12.55 \%$, and up to a maximum loss of $26.19 \%$, consistent with the previous report [9]. It prompted that the change in dose distribution due to the tissue heterogeneity effect was greater in lower-density structures. In the assumption that $\mathrm{MC}$ was the algorithm of highest accuracy it was shown that RT vastly overestimated the target coverage in the middle thoracic spine. With regard to the OARs, the maximum dose discrepancy could be up to $9.2 \%$. Although the average of the dosimetric parameters mainly decreased in the MC plans, some results showed an increase. This means that the RT algorithm probably underestimates the exposure to OARs. For the spinal cord and esophagus, the dose increase could be up to $5.8 \%$ and $4.3 \%$, respectively. This could result in a significant impact on the potential for cord and esophagus injury, especially in the spinal re-irradiation setting where treatment doses and OARs constraints are pushed to tolerance levels. On the other hand, the decreased doses resulting from the $\mathrm{MC}$ recalculation were also consistently observed in the lungs. The average differences 
in $\mathrm{V}_{5}$ and $\mathrm{D}_{\text {mean }}$ between the RT and $\mathrm{MC}$ plans amounted to $5 \%$ and $10 \%$, respectively. It was similar to report evaluating calculation methods in lung cancer ${ }^{[7]}$. Although the overestimation of the lung dose may not lead to any significant treatment-related morbidity, it may reduce the effective tumor dose one can provide to at-risk tumor volumes, taking into account normal tissue tolerances ${ }^{[9]}$.

By contrast, in the upper (T1-T3) and lower thoracic spine (T10-T12), the dose differences were much smaller than in the middle thoracic spine (T4-T9) for target and OARs. The maximum difference of target coverage was less than $5 \%$. Meanwhile, for the spinal cord and esophagus, the maximum differences were both less than $3 \%$. Compared with the $\mathrm{MC}$ algorithm, the dose to the lungs was not consistently overestimated with the RT algorithm, but there was no significant difference. Because, these two sites had less nonadjacent tissue, and only a small number of beams pass through the lung tissues, resulted in slight changes in RT plans compared to MC plans. Thus, the RT algorithm perhaps could be utilized in the upper and lower thoracic spines. The target coverage might be improved by minimizing or avoiding beams traversing the lungs during the planning optimization. There had been evidence that the discrepancies of dose could be effectively reduced in this way ${ }^{[17]}$. Additionally, the use of larger size collimators and lower isodose lines were expected to improve the dosimetric accuracy of RT computation $[3,18]$. Although this way was not a standard, yet it was a practical approach to achieve prescription goals.

A limitation of the present study was the lack of an assessment of the impact of metal implants on dose calculation accuracy. Some patients with multiple vertebral metastases who underwent spine SBRT had metal implants inserted for fixation of the vertebral bodies. It is important to evaluate the effects of these metal implants on spine SBRT, as investigated by some researchers ${ }^{[19-20]}$. In addition, Plans were not subsequently optimized based on the $\mathrm{MC}$ algorithm. Therefore, the extent to which this algorithm can be used to improve the dosimetric parameters is unclear ${ }^{[10]}$.

\section{Conclusions}

For cervical, lumbar and sacral spine lesions, the RT algorithm can be regarded as sufficient and appropriate for accurate calculation of dose. Besides, for the upper and lower thoracic spine, the RT algorithm might also be applied by reducing the number of the beams passing through the lungs. However, in the middle thoracic spine, the RT algorithm should be limited and always verified with the MC algorithm.

\section{Declarations}

Ethics approval and consent to participate $₫$ Not applicable

Funding: This work was partly supported by the National Natural Science Foundation of China (No.81372420), the Beijing Municipal Commission of Science and Technology Collaborative Innovation Project (No.Z201100005620012), Capital's Funds for Health Improvement and Research (No.2020-2Z40919), and the Natural Science Foundation of Beijing (No.7202223). 
Competing interests: The authors declare that they have no competing interests.

Availability of data and material: All data generated or analyzed during this study are included in this published article.

Authors' contributions: $\mathrm{J}$ Li conceived and designed the study. $\mathrm{J} \mathrm{Li}, \mathrm{XL}$ Zhang and $\mathrm{YX}$ Pan performed the experiments. J Li wrote the paper. RJ Yang and HQ Zhuang reviewed and edited the manuscript. All authors read and approved the manuscript.

\section{References}

[1] Sahgal A, Chang JH, Ma L, Marks LB, Milano MT, Medin P, et al. Spinal Cord Dose Tolerance to Stereotactic Body Radiation Therapy. Int J Radiat Oncol Biol Phys. 2019; S0360.

[2]Wu VW, Tam KW, Tong SM. Evaluation of the influence of tumor location and size on the difference of dose calculation between Ray Tracing algorithm and Fast Monte Carlo algorithm in stereotactic body radiotherapy of non-small cell lung cancer using CyberKnife. J Appl Clin Med Phys. 2013;14(5):68-78.

[3] Zheng D, Zhang Q, Liang X, Zhu X, Verma V, Wang S, et al. Effect of the normalized prescription isodose line on the magnitude of Monte Carlo vs. pencil beam target dose differences for lung stereotactic body radiotherapy. J Appl Clin Med Phys. 2016;17(4): 48-58.

[4]Yang J, Liu G, Liu HY, Nie X, Yang ZY, Han J, et al. Influence of CyberKnife Prescription Isodose Line on the Discrepancy of Dose Results Calculated by the Ray Tracing and Monte Carlo Algorithms for Head and Lung Plans: A Phantom Study. Curr Med Sci. 2020;40(2):301-306.

[5]Wilcox EE, Daskalov GM. Accuracy of dose measurements and calculations within and beyond heterogeneous tissues for $6 \mathrm{MV}$ photon fields smaller than $4 \mathrm{~cm}$ produced by Cyberknife. Med Phys. 2008;35(6):2259-2266.

[6] Sharma SC, Ott JT, Williams JB, Dickow D. Clinical implications of adopting Monte Carlo treatment planning for CyberKnife. J Appl Clin Med Phys. 2010;11(1):170-175.

https://doi.org/10.1120/jacmp.v11i1.3142

[7] Kang KM, Jeong BK, Choi HS, Yoo SH, Hwang UJ, Lim YK, et al. Combination effects of tissue heterogeneity and geometric targeting error in stereotactic body radiotherapy for lung cancer using CyberKnife. J Appl Clin Med Phys. 2015;16(5): 193-204.

[8] Zheng D, Zhu X, Zhang Q, Liang X, Zhen W, Lin C,et al. Target dose conversion modeling from pencil beam (PB) to Monte Carlo (MC) for lung SBRT. Radiat Oncol. 2016;11:83.

[9] Okoye CC, Patel RB, Hasan S, Podder T, Khouri A, Fabien J, et al. Comparison of Ray Tracing and Monte Carlo Calculation Algorithms for Thoracic Spine Lesions Treated With CyberKnife-Based Stereotactic Body Radiation Therapy. Technol Cancer Res Treat. 2016;15(1):196-202. 
[10] Wilcox EE, Daskalov GM, Lincoln H. Stereotactic radiosurgery-radiotherapy: Should Monte Carlo treatment planning be used for all sites? Pract Radiat Oncol. 2011;1(4):251-60.

[11] Kaul D, Badakhshi H, Gevaert T, Pasemann D, Budach V, Tuleasca C, et al. Dosimetric comparison of different treatment modalities for stereotactic radiosurgery of meningioma. Acta Neurochir. 2014;157:559-563.

[12] Aljabab S, Vellayappan B, Vandervoort E, Bahm J, Zohr R, Sinclair J, et al. Comparison of four techniques for spine stereotactic body radiotherapy: Dosimetric and efficiency analysis. J Appl Clin Med Phys. 2018;19(2):160-167.

[13] Thibault I, Campbell M, Tseng CL, Atenafu EG, Letourneau D, Yu E,et al. Salvage stereotactic body radiotherapy (SBRT) following in-field failure of initial SBRT for spinal metastases. Int J Radiat Oncol Biol Phys. 2015;93:353-360.

[14] Hwang L, Okoye CC, Patel RB, Sahgal A, Foote M, Redmond KJ, et al. Stereotactic body radiotherapy for benign spinal tumors: Meningiomas, schwannomas, and neurofibromas. J Radiosurg SBRT. 2019;6(3): 167-177

[15] Hariri O, Takayanagi A, Lischalk J, Desai K, Florence TJ, Yazdian P, et al. Clinical Efficacy of Frameless Stereotactic Radiosurgery in the Management of Spinal Metastases from Thyroid Carcinoma. Spine. 2019;44(20):1188-1195.

[16] Kang KM, Jeong BK, Choi HS, Song JH, Park BD, Lim YK, et al. Effectiveness of the Monte Carlo method in stereotactic radiation therapy applied to quasi-homogeneous brain tumors. Oncotarget. 2016;7(11): 12662-12671.

[17] Altman MB, Jin JY, Kim S, Wen N, Liu D, Siddiqui MS, et al. Practical methods for improving dose distributions in Monte Carlo-based IMRT planning of lung wall-seated tumors treated with SBRT. J Appl Clin Med Phys. 2016;13(6):4007.

[18] Wilcox EE, Daskalov GM, Lincoln H, Shumway RC, Kaplan BM, Colasanto JM. Comparison of planned dose distributions calculated by Monte Carlo and Ray-Trace algorithms for the treatment of lung tumors with cyberknife: a preliminary study in 33 patients. Int J Radiat Oncol Biol Phys. 2010;77(1):277-284.

[19] Huang JY, Followill DS, Howell RM, Liu X, Mirkovic D, Stingo FC, et al. Approaches to reducing photon dose calculation errors near metal implants. Med Phys. 2016;43(9):5117-5130.

[20]Akyol O, Dirican B, Toklu T, Eren H, Olgar T. Investigating the effect of dental implant materials with different densities on radiotherapy dose distribution using Monte-Carlo simulation and pencil beam convolution algorithm. Dentomaxillofac Radiol. 2019;48(4):20180267.

\section{Tables}


Table 1 Patient and tumor characteristics

\begin{tabular}{|c|c|c|c|c|c|c|c|}
\hline Site & $\begin{array}{l}\text { Number of } \\
\text { patients }\end{array}$ & $\begin{array}{c}\text { Tumor } \\
\text { location }\end{array}$ & $\begin{array}{c}\text { Prescription } \\
\text { dose (Gy) }\end{array}$ & $\begin{array}{l}\text { Number of } \\
\text { fractions }\end{array}$ & $\begin{array}{l}\text { Prescription } \\
\text { Isodose }\end{array}$ & $\begin{array}{c}\text { Collimator } \\
\text { Sizes } \\
(\mathrm{mm})\end{array}$ & $\begin{array}{c}\text { PTV } \\
\text { Volume } \\
\text { (cc) }\end{array}$ \\
\hline \multirow{3}{*}{$\begin{array}{l}\text { Cervical } \\
\text { spine }\end{array}$} & 9 & C1-2 & $27-30$ & \multirow[t]{3}{*}{3} & \multirow[t]{3}{*}{$70 \%-77 \%$} & \multirow[t]{3}{*}{$10-50$} & \multirow{3}{*}{$\begin{array}{l}87.2- \\
204.6\end{array}$} \\
\hline & 14 & C3-5 & $24-30$ & & & & \\
\hline & 7 & C6-7 & $27-30$ & & & & \\
\hline \multirow{4}{*}{$\begin{array}{l}\text { Thoracic } \\
\text { spine }\end{array}$} & 14 & T1-3 & $27-30$ & \multirow[t]{4}{*}{3} & \multirow[t]{4}{*}{$68 \%-80 \%$} & \multirow[t]{4}{*}{$12.5-50$} & \multirow{4}{*}{$\begin{array}{l}51.7- \\
303.5\end{array}$} \\
\hline & 11 & T4-6 & $24-30$ & & & & \\
\hline & 10 & T7-9 & $27-30$ & & & & \\
\hline & 15 & T10-12 & $24-30$ & & & & \\
\hline \multirow{2}{*}{$\begin{array}{l}\text { Lumbar } \\
\text { spine }\end{array}$} & 13 & L1-2 & $24-30$ & \multirow[t]{2}{*}{3} & \multirow[t]{2}{*}{$69 \%-81 \%$} & \multirow[t]{2}{*}{$10-60$} & 108.3- \\
\hline & 17 & L3-5 & $24-30$ & & & & 319.8 \\
\hline $\begin{array}{l}\text { Sacral } \\
\text { spine }\end{array}$ & 15 & S1 & $27-30$ & 3 & $71 \%-84 \%$ & $12.5-60$ & $\begin{array}{l}67.4- \\
228.1 \\
\end{array}$ \\
\hline
\end{tabular}

Table 2 Dose parameters of cervical spine lesions

\begin{tabular}{|c|c|c|c|c|}
\hline Site & Dosimetric parameter & $\begin{array}{r}\text { Ray Tracing } \\
(\text { mean } \pm \text { SD) }\end{array}$ & $\begin{array}{l}\text { Monte Carlo } \\
(\text { mean } \pm \text { SD) }\end{array}$ & P-Value \\
\hline \multirow[t]{12}{*}{ C1-2 } & PTV & & & \\
\hline & $\mathrm{V}_{100 \%}$ & $95.40 \% \pm 0.43 \%$ & $96.28 \% \pm 1.41 \%$ & $<0.01$ \\
\hline & Spinal Cord & & & \\
\hline & $\mathrm{D}_{\max }(\mathrm{Gy})$ & $24.15 \pm 3.94$ & $24.48 \pm 3.83$ & 0.12 \\
\hline & $\mathrm{D}_{0.1 \mathrm{cc}}(\mathrm{Gy})$ & $20.66 \pm 3.98$ & $21.09 \pm 3.84$ & 0.08 \\
\hline & $\mathrm{D}_{1 \mathrm{cc}}(\mathrm{Gy})$ & $15.85 \pm 4.79$ & $16.13 \pm 4.74$ & 0.15 \\
\hline & $\mathrm{D}_{5 \mathrm{cc}}(\mathrm{Gy})$ & $10.23 \pm 6.77$ & $10.40 \pm 6.33$ & 0.46 \\
\hline & Oral mucosa & & & \\
\hline & $\mathrm{D}_{\max }(\mathrm{Gy})$ & $24.86 \pm 67.3$ & $25.00 \pm 6.92$ & 0.17 \\
\hline & $\mathrm{D}_{0.1 \mathrm{cc}}(\mathrm{Gy})$ & $23.20 \pm 6.60$ & $23.31 \pm 6.72$ & 0.51 \\
\hline & $\mathrm{D}_{1 \mathrm{cc}}(\mathrm{Gy})$ & $20.14 \pm 6.25$ & $20.27 \pm 6.47$ & 0.33 \\
\hline & $\mathrm{D}_{5 \mathrm{cc}}(\mathrm{Gy})$ & $15.85 \pm 5.38$ & $15.93 \pm 5.69$ & 0.42 \\
\hline \multirow[t]{12}{*}{ C3-7 } & PTV & & & \\
\hline & $\mathrm{V}_{100}$ & $95.33 \% \pm 0.50 \%$ & $93.92 \% \pm 1.27 \%$ & $<0.01$ \\
\hline & Spinal Cord & & & \\
\hline & $\mathrm{D}_{\max }(\mathrm{Gy})$ & $25.15 \pm 2.71$ & $24.74 \pm 2.58$ & 0.02 \\
\hline & $\mathrm{D}_{0.1 \mathrm{cc}}(\mathrm{Gy})$ & $22.42 \pm 3.24$ & $22.15 \pm 3.06$ & 0.08 \\
\hline & $\mathrm{D}_{1 \mathrm{cc}}(\mathrm{Gy})$ & $17.53 \pm 4.82$ & $16.97 \pm 4.52$ & 0.05 \\
\hline & $\mathrm{D}_{5 \mathrm{cc}}(\mathrm{Gy})$ & $8.65 \pm 6.52$ & $8.24 \pm 6.53$ & 0.42 \\
\hline & Esophagus & & & \\
\hline & Dmax & $27.04 \pm 3.48$ & $26.69 \pm 3.12$ & 0.07 \\
\hline & $\mathrm{D}_{0.1 \mathrm{cc}}(\mathrm{Gy})$ & $24.81 \pm 4.74$ & $24.34 \pm 4.26$ & 0.21 \\
\hline & $\mathrm{D}_{1 \mathrm{cc}}(\mathrm{Gy})$ & $20.72 \pm 4.96$ & $20.34 \pm 4.58$ & 0.13 \\
\hline & $\mathrm{D}_{5 \mathrm{cc}}(\mathrm{Gy})$ & $13.56 \pm 5.18$ & $13.24 \pm 4.70$ & 0.07 \\
\hline
\end{tabular}

Table 3 Dose parameters of thoracic lesions 


\begin{tabular}{|c|c|c|c|c|}
\hline Site & Dosimetric parameter & $\begin{array}{l}\text { Ray Tracing } \\
(\text { mean } \pm \text { SD) }\end{array}$ & $\begin{array}{l}\text { Monte Carlo } \\
(\text { mean } \pm \text { SD) }\end{array}$ & P-Value \\
\hline \multirow[t]{18}{*}{ T1-3 } & PTV & & & \\
\hline & $\mathrm{V}_{100 \%}$ & $94.93 \% \pm 0.39 \%$ & $91.86 \% \pm 3.46 \%$ & $<0.01$ \\
\hline & Spinal Cord & & & \\
\hline & $\mathrm{D}_{\max }(\mathrm{Gy})$ & $22.01 \pm 1.88$ & $21.59 \pm 2.01$ & 0.02 \\
\hline & $\mathrm{D}_{0.1 \mathrm{cc}}(\mathrm{Gy})$ & $19.44 \pm 3.22$ & $18.90 \pm 2.42$ & 0.03 \\
\hline & $\mathrm{D}_{1 \mathrm{cc}}(\mathrm{Gy})$ & $15.85 \pm 1.79$ & $15.46 \pm 2.00$ & 0.33 \\
\hline & $\mathrm{D}_{5 \mathrm{cc}}(\mathrm{Gy})$ & $10.23 \pm 3.49$ & $10.11 \pm 3.15$ & 0.46 \\
\hline & Esophagus & & & \\
\hline & $\mathrm{D}_{\max }(\mathrm{Gy})$ & $25.10 \pm 2.23$ & $24.36 \pm 2.03$ & 0.02 \\
\hline & $\mathrm{D}_{0.1 \mathrm{cc}}(\mathrm{Gy})$ & $22.07 \pm 1.47$ & $21.25 \pm 2.06$ & 0.02 \\
\hline & $\mathrm{D}_{1 \mathrm{cc}}(\mathrm{Gy})$ & $19.20 \pm 1.74$ & $18.51 \pm 1.62$ & 0.02 \\
\hline & $\mathrm{D}_{5 \mathrm{cc}}(\mathrm{Gy})$ & $13.69 \pm 2.51$ & $13.02 \pm 2.14$ & 0.42 \\
\hline & Left Lung & & & \\
\hline & $\mathrm{V}_{5}$ & $20.2 \% \pm 4.6 \%$ & $19.1 \% \pm 8.4 \%$ & 0.02 \\
\hline & $\mathrm{D}_{\text {mean }}(\mathrm{Gy})$ & $3.21 \pm 0.48$ & $3.15 .3 \pm 0.71$ & 0.04 \\
\hline & Right Lung & & & \\
\hline & $\mathrm{V}_{5}$ & $26.8 \% \pm 6.7 \%$ & $24.3 \% \pm 9.3 \%$ & 0.02 \\
\hline & $\mathrm{D}_{\text {mean }}(\mathrm{Gy})$ & $4.75 \pm 1.06$ & $4.67 \pm 1.23$ & 0.02 \\
\hline \multirow[t]{18}{*}{ T4-9 } & PTV & & & \\
\hline & $\mathrm{V}_{100 \%}$ & $95.22 \% \pm 0.51 \%$ & $82.67 \% \pm 13.68 \%$ & $<0.01$ \\
\hline & Spinal Cord & & & \\
\hline & $\mathrm{D}_{\max }$ & $22.80 \pm 3.93$ & $21.76 \pm 4.24$ & $<0.01$ \\
\hline & $\mathrm{D}_{0.1 \mathrm{cc}}(\mathrm{Gy})$ & $19.28 \pm 3.81$ & $18.32 \pm 3.57$ & $<0.01$ \\
\hline & $\mathrm{D}_{1 \mathrm{cc}}(\mathrm{Gy})$ & $16.82 \pm 4.45$ & $16.47 \pm 4.02$ & 0.05 \\
\hline & $\mathrm{D}_{5 \mathrm{cc}}(\mathrm{Gy})$ & $7.49 \pm 5.06$ & $7.22 \pm 5.61$ & 0.42 \\
\hline & Esophagus & & & \\
\hline & $\mathrm{D}_{\max }(\mathrm{Gy})$ & $23.57 \pm 3.52$ & $22.48 \pm 2.84$ & $<0.01$ \\
\hline & $\mathrm{D}_{0.1 \mathrm{cc}}(\mathrm{Gy})$ & $21.22 \pm 3.27$ & $20.16 \pm 3.53$ & $<0.01$ \\
\hline & $\mathrm{D}_{1 \mathrm{cc}}(\mathrm{Gy})$ & $18.46 \pm 3.83$ & $17.94 \pm 3.53$ & 0.03 \\
\hline & $\mathrm{D}_{5 \mathrm{cc}}(\mathrm{Gy})$ & $13.86 \pm 4.35$ & $13.34 \pm 4.67$ & 0.02 \\
\hline & Left Lung & & & \\
\hline & $\mathrm{V}_{5}$ & $28.40 \% \pm 18.4 \%$ & $25.97 \pm 13.80 \%$ & $<0.01$ \\
\hline & $\mathrm{D}_{\text {mean }}(\mathrm{Gy})$ & $5.77 \pm 1.83$ & $5.29 \pm 1.55$ & $<0.01$ \\
\hline & Right Lung & & & \\
\hline & $\mathrm{V}_{5}$ & $34.2 \% \pm 18.9 \%$ & $31.8 \% \pm 15.2 \%$ & $<0.01$ \\
\hline & $\mathrm{D}_{\text {mean }}(\mathrm{Gy})$ & $6.53 \pm 2.25$ & $6.01 \pm 1.72$ & $<0.01$ \\
\hline \multirow[t]{16}{*}{ T10-12 } & PTV & & & \\
\hline & $\mathrm{V}_{100 \%}$ & $95.14 \% \pm 0.27 \%$ & $91.56 \% \pm 2.18 \%$ & $<0.01$ \\
\hline & Spinal Cord & & & \\
\hline & $\mathrm{D}_{\max }$ & $22.61 \pm 2.80$ & $22.09 \pm 2.89$ & 0.02 \\
\hline & $\mathrm{D}_{0.1 \mathrm{cc}}(\mathrm{Gy})$ & $20.71 \pm 2.39$ & $20.14 \pm 2.52$ & 0.05 \\
\hline & $\mathrm{D}_{1 \mathrm{cc}}(\mathrm{Gy})$ & $18.01 \pm 241$ & $17.57 \pm 2.45$ & 0.03 \\
\hline & $\mathrm{D}_{5 \mathrm{cc}}(\mathrm{Gy})$ & $94.2 \pm 6.74$ & $9.13 \pm 7.20$ & 0.07 \\
\hline & Esophagus & & & \\
\hline & $\mathrm{D}_{\max }(\mathrm{Gy})$ & $20.71 \pm 3.78$ & $20.28 \pm 4.14$ & 0.07 \\
\hline & $\mathrm{D}_{0.1 \mathrm{cc}}(\mathrm{Gy})$ & $18.83 \pm 4.15$ & $18.60 \pm 4.14$ & 0.21 \\
\hline & $\mathrm{D}_{1 \mathrm{cc}}(\mathrm{Gy})$ & $16.35 \pm 4.74$ & $15.93 \pm 5.01$ & 0.01 \\
\hline & $\mathrm{D}_{5 \mathrm{cc}}(\mathrm{Gy})$ & $12.75 \pm 5.76$ & $12.31 \pm 5.95$ & 0.01 \\
\hline & Left Lung & & & \\
\hline & $\mathrm{V}_{5}$ & $21.11 \% \pm 14.8 \%$ & $19.81 \% \pm 13.90 \%$ & 0.02 \\
\hline & $\mathrm{D}_{\text {mean }}(\mathrm{Gy})$ & $4.36 \pm 2.42$ & $4.21 \pm 1.61$ & 0.03 \\
\hline & Right Lung & & & \\
\hline
\end{tabular}




\begin{tabular}{llll}
$\mathrm{V}_{5}$ & $15.22 \% \pm 8.6 \%$ & $14.72 \% \pm 10.7 \%$ & 0.02 \\
\hline $\mathrm{D}_{\text {mean }}$ (Gy) & $3.66 \pm 1.56$ & $3.53 \pm 1.34$ & 0.03 \\
\hline
\end{tabular}

Table 4 Dose parameters of lumbar lesions

\begin{tabular}{|c|c|c|c|c|}
\hline Site & Dosimetric parameter & $\begin{array}{l}\text { Ray Tracing } \\
(\text { mean } \pm \text { SD) }\end{array}$ & $\begin{array}{l}\text { Monte Carlo } \\
(\text { mean } \pm \text { SD) }\end{array}$ & p-Value \\
\hline \multirow{23}{*}{ L1-5 } & PTV & & & \\
\hline & $\mathrm{V}_{100 \%}$ & $95.3 \% \pm 0.58 \%$ & $92.86 \% \pm 1.14 \%$ & $<0.01$ \\
\hline & $\begin{array}{l}\text { Spinal Cord/ } \\
\text { Cauda equina }\end{array}$ & & & \\
\hline & $\mathrm{D}_{\max }$ & $25.80 \pm 4.35$ & $25.54 \pm 4.46$ & 0.02 \\
\hline & $\mathrm{D}_{0.1 \mathrm{cc}}(\mathrm{Gy})$ & $23.83 \pm 4.60$ & $23.54 \pm 4.97$ & 0.08 \\
\hline & $\mathrm{D}_{1 \mathrm{cc}}(\mathrm{Gy})$ & $20.71 \pm 4.14$ & $20.49 \pm 4.50$ & 0.15 \\
\hline & $\mathrm{D}_{5 \mathrm{cc}}(\mathrm{Gy})$ & $12.60 \pm 4.49$ & $12.46 \pm 4.95$ & 0.46 \\
\hline & Bowel & & & \\
\hline & Dmax & $23.28 \pm 3.14$ & $22.93 \pm 2.35$ & 0.17 \\
\hline & $\mathrm{D}_{0.1}(\mathrm{~Gy})$ & $22.01 \pm 3.86$ & $21.89 \pm 3.09$ & 0.51 \\
\hline & $\mathrm{D}_{1 \mathrm{cc}}(\mathrm{Gy})$ & $20.21 \pm 4.06$ & $20.55 \pm 6.48$ & 0.33 \\
\hline & $\mathrm{D}_{5 \mathrm{cc}}(\mathrm{Gy})$ & $16.69 \pm 4.04$ & $16.96 \pm 4.86$ & 0.04 \\
\hline & Stomach & & & \\
\hline & Dmax & $16.72 \pm 7.34$ & $16.62 \pm 7.18$ & 0.04 \\
\hline & $\mathrm{D}_{0.1}(\mathrm{~Gy})$ & $14.64 \pm 6.89$ & $14.51 \pm 6.52$ & 0.45 \\
\hline & $\mathrm{D}_{1 \mathrm{cc}}(\mathrm{Gy})$ & $12.40 \pm 7.03$ & $12.18 \pm 7.18$ & 0.06 \\
\hline & $\mathrm{D}_{5 \mathrm{cc}}(\mathrm{Gy})$ & $10.13 \pm 6.55$ & $9.78 \pm 6.73$ & 0.02 \\
\hline & Left Kidney & & & \\
\hline & $\mathrm{D}_{\text {mean }}(\mathrm{Gy})$ & $10.24 \pm 3.48$ & $10.59 \pm 3.12$ & 0.07 \\
\hline & $\mathrm{V}_{1600}(\mathrm{CC})$ & $81.30 \pm 4.40$ & $79.7 \pm 6.20$ & 0.21 \\
\hline & Right Kidney & & & \\
\hline & $\mathrm{D}_{\text {mean }}(\mathrm{Gy})$ & $12.28 \pm 4.74$ & $12.14 \pm 4.26$ & 0.11 \\
\hline & $\mathrm{V}_{1600}(\mathrm{cc})$ & $10.43 \pm 4.96$ & $10.29 \pm 4.58$ & 0.13 \\
\hline
\end{tabular}


Table 5 Dose parameters of sacral lesions

\begin{tabular}{|c|c|c|c|c|}
\hline \multirow{13}{*}{$\begin{array}{l}\text { Site } \\
\text { S1 }\end{array}$} & Dosimetric parameter & Ray Tracing $($ mean \pm SD) & Monte Carlo (mean \pm SD) & p-Value \\
\hline & \multicolumn{4}{|l|}{ PTV } \\
\hline & $\mathrm{V}_{100 \%}$ & $95.23 \% \pm 0.67 \%$ & $93.87 \% \pm 1.02 \%$ & $<0.01$ \\
\hline & \multicolumn{4}{|l|}{ Cauda equina } \\
\hline & $\mathrm{D}_{\max }$ & $23.51 \pm 3.44$ & $23.38 \pm 3.24$ & 0.02 \\
\hline & $\overline{\mathrm{D}_{0.1 \mathrm{cc}}}$ & $20.80 \pm 3.69$ & $20.90 \pm 3.54$ & 0.02 \\
\hline & $\mathrm{D}_{1 \mathrm{cc}}$ & $15.85 \pm 4.03$ & $15.73 \pm 3.88$ & 0.15 \\
\hline & $\mathrm{D}_{5 \mathrm{cc}}$ & $12.13 \pm 3.77$ & $12.22 \pm 3.34$ & 0.46 \\
\hline & \multicolumn{4}{|l|}{ Bowel } \\
\hline & $\mathrm{D}_{\max }$ & $24.91 \pm 5.64$ & $24.70 \pm 5.42$ & 0.17 \\
\hline & $\mathrm{D}_{0.1}$ & $23.01 \pm 5.60$ & $23.15 \pm 5.47$ & 0.32 \\
\hline & $\mathrm{D}_{1 \mathrm{cc}}$ & $20.34 \pm 5.25$ & $20.25 \pm 5.18$ & 0.51 \\
\hline & $\mathrm{D}_{5 \mathrm{cc}}$ & $15.85 \pm 5.46$ & $15.54 \pm 5.33$ & 0.04 \\
\hline
\end{tabular}

\section{Figures}




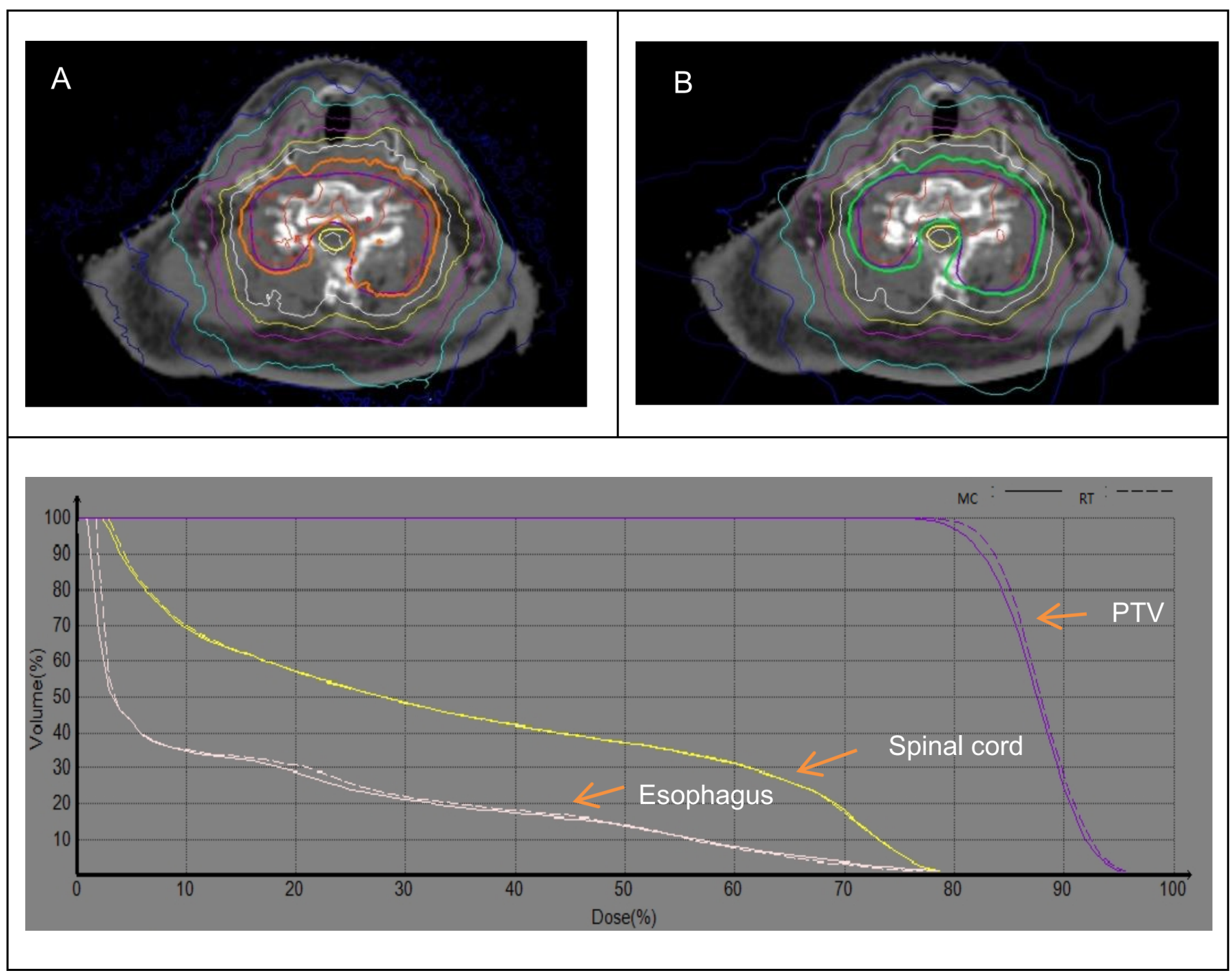

Fig. 1 Dose distribution and DVH between the MC (a) and RT (b) algorithms for cervical spine.

\section{Figure 1}

Figure 1 demonstrated the dose distribution and DVHs for cervical spine lesions between the RT and MC algorithms. 


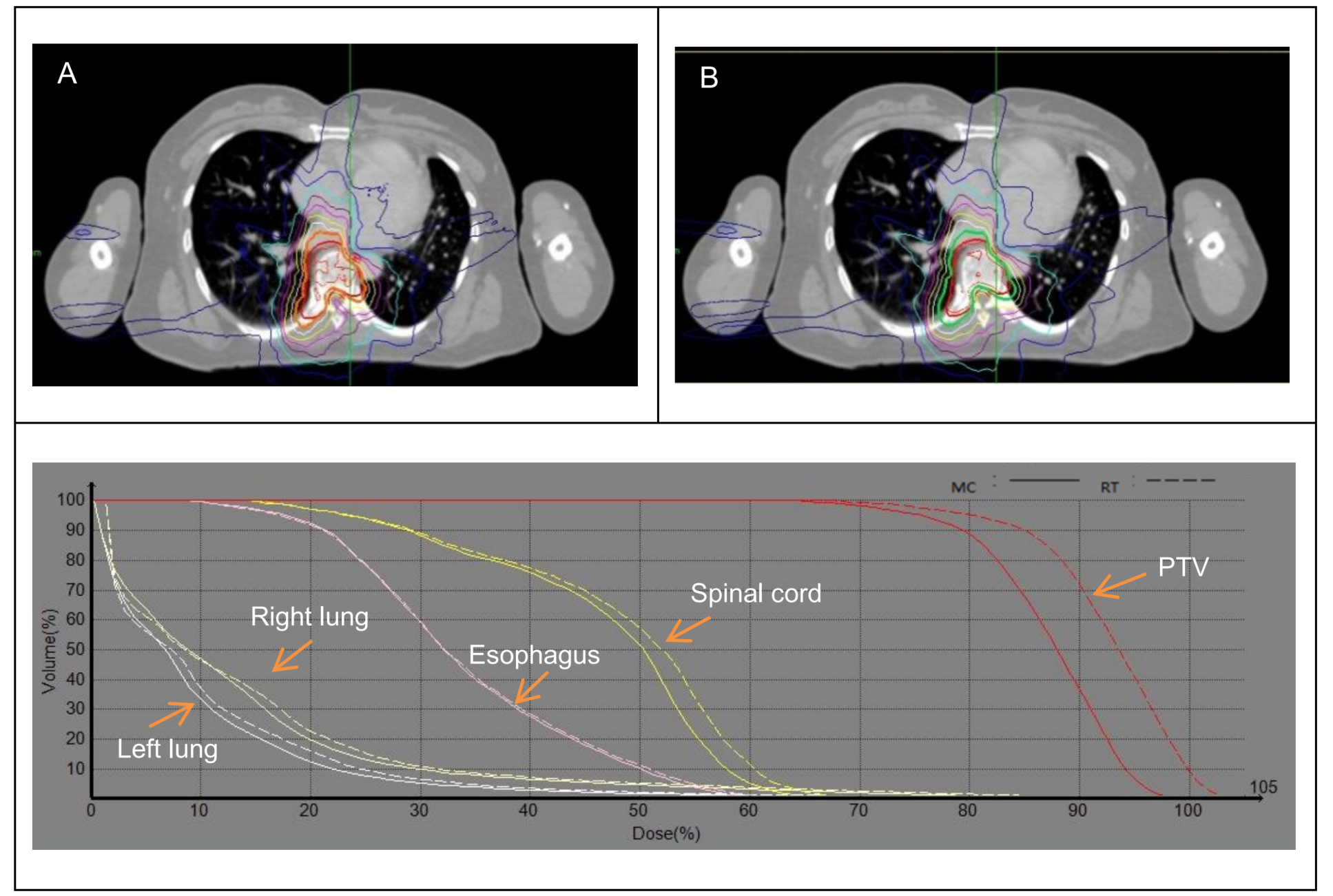

Fig. 2 Dose distribution and DVH between the MC (a) and RT (b) algorithms for 6th thoracic spine

\section{Figure 2}

The average deviations were generally less than $5 \%$ in V 5 and less than $10 \%$ in Dmean. Based on the results shown in Figure 2, we found that the RT algorithm obviously overestimated the V100 of PTV compared to the $\mathrm{MC}$ algorithm. 


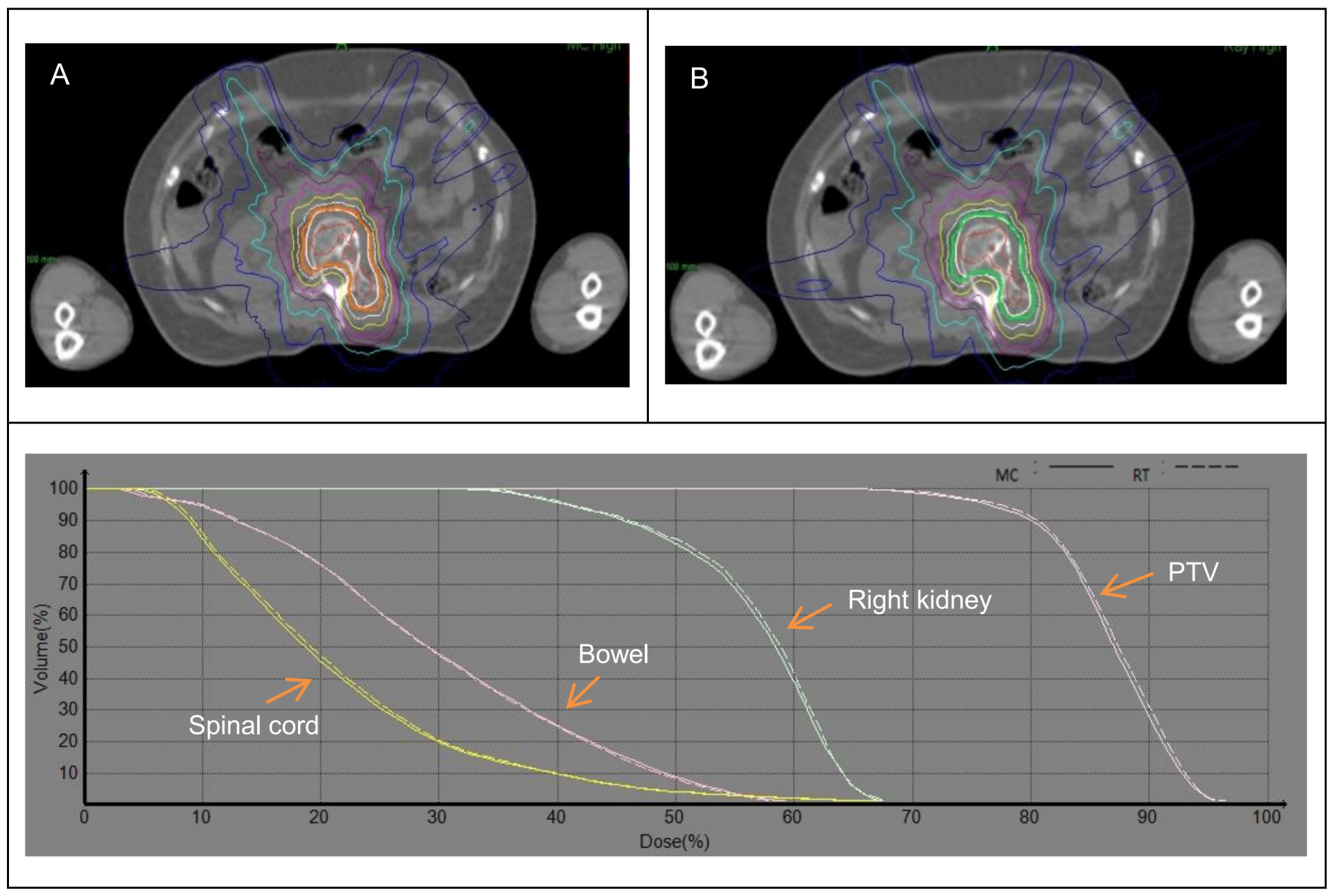

Fig. 3 Dose distribution and DVH between the MC (a) and RT (b) algorithms for lumbar spine

\section{Figure 3}

For OARs, the dose difference between the RT and $\mathrm{MC}$ algorithms was not remarkable, and RT/MC ratio ranged from 0.982 to 1.028. From DVHs shown in Figure 3, the coverage of PTV and dose of OARs was basically unchanged. 


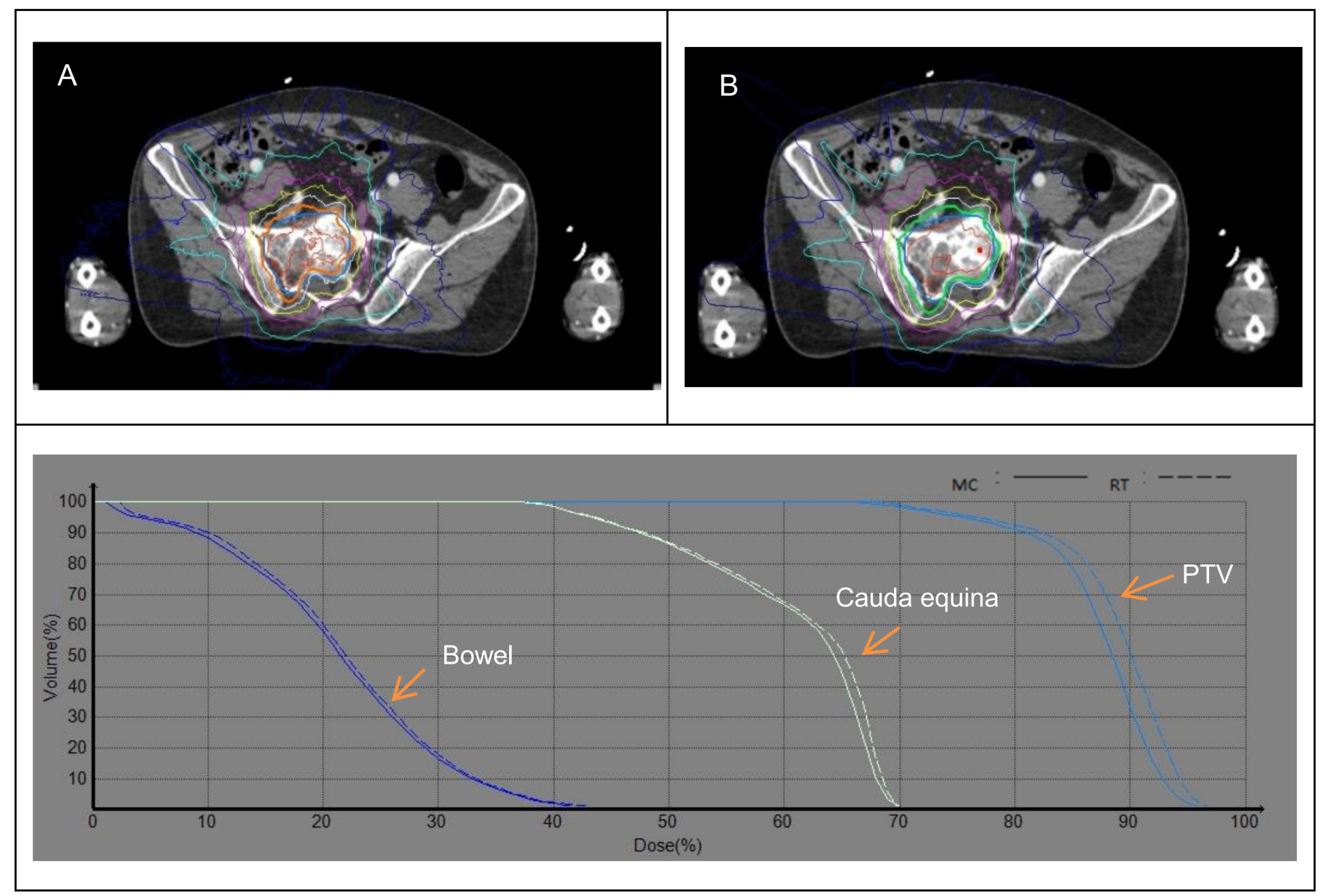

Fig. 4. Dose distribution and DVH between the MC (a) and RT (b) algorithms for sacral spine

Figure 4

. As shown in Figure 4, the increased dose was displayed in RT plans compared to MC plans in DVHs. But the dose distribution of the MC algorithm was closer to the RT algorithm for OARs and PTV coverage of prescription dose. 